\title{
Anti Fraud Culture and Care in Indonesian Banking
}

\author{
Ida Nurhayati ${ }^{1}$, Abdillah ${ }^{2}$, Titik Purwinarti ${ }^{3}$ \\ \{ida.nurhayati@akuntansi.pnj.ac.id ${ }^{1}$, abdillahpnj@gmail.com², titikpurwinarti@yahoo.com ${ }^{3}$ \} \\ Politeknik Negeri Jakarta, Indonesia ${ }^{1,2,3}$
}

\begin{abstract}
This research is the first part to know the culture and concern of the bankers towards anti fraud. It was intended to precauation and prevention. In conducting this research using qualitative methods with normative sociological, cultural and juridical approaches, through primary and secondary data. From these data verification was also carried out through Focus Group Discussion (FGD) with experts, practitioners, and academics in the banking sector. The result, that anti-fraud has been regulated in the Bank Indonesia Regulation and socialized through regulations in each bank. In general, it is carried out legally by prioritizing legal aspects as guidelines. Concern for anti fraud is based more on the existence of legal rules that are formally legal. The existence of regulations related to antifraud is felt to be sufficient to prevent and prevent fraud in banks.
\end{abstract}

Keywords: anti fraud banking prevention countermeasures.

\section{Introduction}

Banking, as one part of the financial business, which relies on people's trust in their work, with their expertise in managing the financial community (customers). This trust is often a misused moment by all those involved in bank operations to reduce the community (customers) with various modus operandi that can harm the community/its customers.

Fraud in the banking system if it is in acondition of low integrity, weak control, low accountability, and high pressure, the chances of someone being dishonest will be even greater. Based on the fraud triangle theory, pressure, opportunity, and rationalization that come together will increase the chances of fraud.

Fraud generally occurs because of three main things, namely: the existence of pressure to commit fraud, the opportunity that can be exploited and the justification for the action. In principle Fraud has three elements, namely: the existence of illegal acts; carried out by people from within and / or from outside the organization and carried out to obtain personal and / or group benefits while on the other hand harming other parties both directly and indirectly.

The Financial Services Authority (OJK) recorded a total of 108 banking criminal cases for almost two years (2014-2016). Most types of fraud cases in banking are credit cases, including credit card data, theft of credit card data, incorrect recording, and others. Members of the OJK Board of Commissioners or as Chief Executive of Banking Superintendents, Nelson Tampubolon 
in the Socialization of Handling Alleged Banking Crime and Anti Forum Fraud, said, banking operational activities have high complexity against irregularities, both administratively and leading to criminal acts or fraud.

Table 1.1. Case Of Fraud (Cheating) in Banking 2014-2016

\begin{tabular}{|c|c|c|}
\hline No & Case Type & Percentage(\%) \\
\hline 1 & Credit & 55 \\
\hline 2 & Ruse Fund Embursement & 21 \\
\hline 3 & Fund Embezzlement & 15 \\
\hline 4 & Fund Transfer & 5 \\
\hline 5 & Source: Ariyanti, 2016 & Procurement o \\
\cline { 2 - 3 }
\end{tabular}

From the data above shows that the biggest fraud / fraud in the credit sector which reaches $55 \%$ indicates that credit is still a part that can encourage someone or several people to commit fraud. Tampubolon (2016) perpetrators of fraud are usually individuals who are authorized to make decisions, and are related to handling banking operations. "Fraud in banking occurs mostly in rural banks (BPR), 80 percent are closed due to fraud (Ariyanti, 2016).

Fraud according to Bank Indonesia Circular Letter No.13 / 28 / DPNP dated December 9, 2011 is a deliberate act of deviation or omission to deceive, deceive, or manipulate a Bank, customer, or other party, which occurs in the Bank and / or uses facilities The Bank thus causes the Bank, customer, or other party to suffer losses and / or fraud perpetrators to obtain financial benefits both directly and indirectly. The types of actions classified as fraud are fraud, fraud, embezzlement of assets, leakage of information, banking crimes and other actions that can be likened to it [1].

The results of Albrecht (1994) and Koletar (2003) states that there are three things that cause a person to conduct fraud, namely: preassure (pressure), opportunity (opportunity) and rasionalization (justification). Pressure or pressure is generally caused due to the individual behavior of employees that cause it do Fraud. It could be that the pressure is caused by financial problems (financial pressure) triggered by excessive lifestyles, greed and greed, a lot of debt or dependents and so on, which causes a person "forced" to do Fraud [2]. In general elements of fraud :

1. misrepresentation;

2. past or present;

3. fact is material;

4. make-knowingly or recklessly;

5. with intent to cause a party to act;

6. the aggrieved party must act against the wrong statement;

7. detriment.

\section{Essense Of Banking Institution}


A bank is a financial institution whose principal business is providing credit services in payment and circulation traffic. Financial institutions are all entities whose activities attract money from the community and distribute it to the public. So the main task of banks as financial institutions is, active credit operations, namely the creation or provision of credit by banks, and passively accepting deposits in the form of demand deposits, deposits, savings or other forms of deposit entrusted by the public [3]. The essence of a bank is how to transform an "intangible" commodity in the form of trust, which is the true value of a bank. How do banks attract and use money from the public, and managing money from the community will form their own image or image in the minds of the community. It is this trustworthy commodity that gives the bank a sense of responsibility both morally and financially.

\subsection{Fraud}

Fraud according to Bank Indonesia Circular No.13 / 28 / DPNP dated 9 December 2011 is an act of deviation or omission that is intentionally carried out to deceive, cheat, or manipulate the Bank, customers or other parties that occur within the Bank and / or use the Banks so that banks, customers or other parties suffer losses and / or fraud perpetrators obtain financial benefits both directly and indirectly.The types of actions classified as fraud are fraud, fraud, asset embezzlement, information leakage, banking crime and other actions that can be equated with it (Triana, 2012).In the banking industry, the existence of the Fraud status is an integral part. For this reason, it is necessary to understand the term Fraud according to the Black Law Dictionary:

1. A knowing misrepresentation of the truth or concealment of a material fact to induce another to act to his or her detriment; is usual a tort, but in some cases (esp. when the conduct is willful) it may be a crime,

2. A misrepresentation made recklessly without belief in its truth to induce another person to act,

3. A tort arising from knowing misrepresentation, concealment of material fact, or reckless misrepresentation made toinduce another to act to his or her detriment.

The results of Albrecht (1994) and Koletar (2003) states that there are three things that cause a person to do Fraud, namely: preassure (pressure), opportunity (rationale) and rationalization (justification). Pressure or pressure is generally caused by the individual behavior of employees that cause it do Fraud. It could be that pressure is caused by financial problems that are triggered by excessive lifestyles, greed and greed, lots of debt or dependents, etc. that cause someone to "be forced" to do Fraud [4].

\subsection{Element Fraud}

The definition of fraud above, it is illustrated that what is meant by fraud is very broad and can be seen in several categories of fraud. But in general, the elements of fraud (the whole element must exist, if there are none that are considered fraud is not considered) are:

1. There must be a false statement;

2. from a past or present;

3. facts are material;

4. done intentionally or without calculation; 
5. with the intention to cause a party to act;

6 . The aggrieved party must act against the wrong statement which is detrimental to it.

\subsection{Fraud Classification}

The Association of Certified Fraud Examiners (ACFE) is a professional organization engaged in the examination of fraud that is domiciled in the United States and has the aim of eradicating fraud, classifying fraud in several classifications, and known as the term "fraud." Fraud Tree "which is a Classification System Regarding Things That Are Caused by Fraud (Uniform Occupational Fraud Classification System).

\subsection{Anti Fraud Culture}

Vocational culture can prevent various irregularities or abuse of authority including corruption. In this case culture can be interpreted as a value that can be accepted by the general public. Honesty can be accepted and practiced as a habit that can be cultivated. In building a culture of honesty in an organization it is very important that it can be started from the leader. To be socialized, the code of conduct is arranged as a standard for all members of the organization [5].The strategy of building an anti-fraud culture is a manifestation of the commitment of bank management to control fraud that can be applied in the form of a fraud control system. This strategy requires management to implement resources so that the fraud control system can be implemented effectively and continuously [6].

\subsection{Anti Fraud Strategy}

Anti-Fraud Strategy is a manifestation of organizational commitment in this case the banking sector in controlling fraud. The Anti Fraud Strategy and procedure was issued on June 1, 2012. The legal basis for implementing the Anti-Fraud Strategy is (1) Bank Indonesia Circular Letter Number 13/28 / DPNP dated December 9, 2011 concerning the Implementation of Anti-Fraud Strategies for Commercial Banks. (2) Bank Indonesia Circular Letter Number 13/23 / DPNP dated October 25, 2011 concerning Amendments to Circular Letter No. 5/21 / DPNP concerning Application of Risk Management for Commercial Banks. (3) Banking Law Number 7/1992 as amended by Law Number 10/1998.

In Bank Indonesia Circular No. 13/28/DPNP/ December 9, 2011 concerning The implementation of the Anti-Fraud Strategy for Commercial Banks states that banks are required to have and implement an anti-fraud strategy that is tailored to the internal and external environment, the complexity of business activities, potential, types and risk of fraud and supported by adequate resources. This strategy applies to commercial banks, which are referred to as commercial banks in this circular letter are commercial banks that carry out conventional business activities and / or activities based on sharia principles.

The implementation of the Anti-Fraud Strategy based on fraud control systems, has 4 pillars, as contained in Bank Indonesia Circular No. 13/28 / DPNP / December 9, 2011 namely:a) prevention, which contains tools in order to reduce the potential for fraud, which includes anti fraud awareness, vulnerability identification, and know your employee, b) detection: contains instruments in order to identify and find fraud events in the bank's business activities, which include policies and mechanisms for whistleblowing, surprise audits, and surveillance systems.c) investigation, reporting, and sanctions: contain instruments in order to explore information, 
reporting systems, and impose sanctions for fraudulent events in bank business activities, including investigative standards, reporting mechanisms, and imposing sanctionsd) monitoring, evaluation, and follow-up is part of the fraud control system that contains steps in order to monitor and evaluate fraud, as well as follow-up mechanisms [7].

Dewi, YR and Ariandi [8] in their results stated that, internal control and anti-fraud awareness had a significant impact on fraud prevention. This shows that the act of committing fraud can be prevented by establishing good internal controls and increasing awareness of anti-fraud (fraud) to all parties in the banking organization.

Uniform Occupational Fraud Classification System

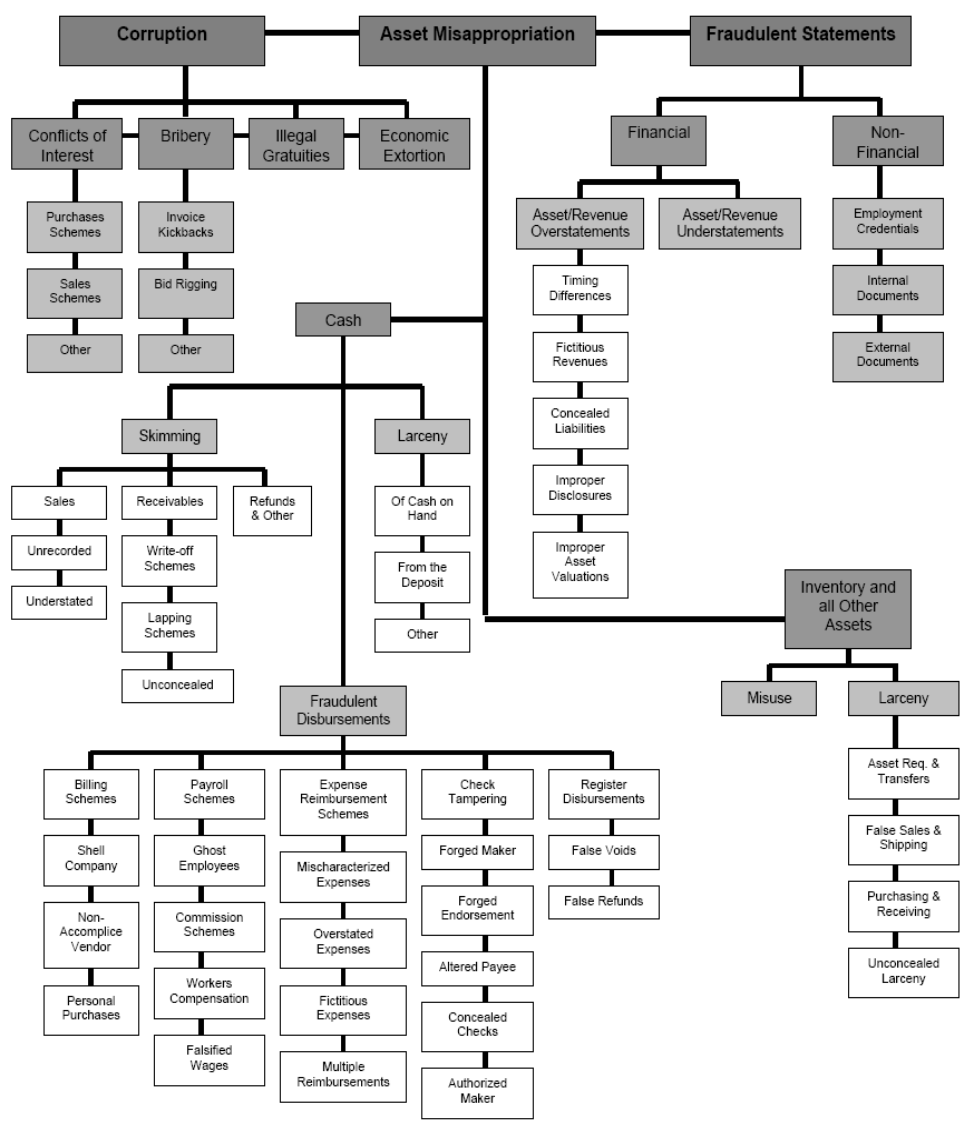

Source: The Association of Certified Fraud Examiners 2004 Report to the Nation on Occupational Fraud and Abuse

Uniform Occupational Fraud Classification System, The ACFE divides Fraud (Fraud) in 3 (three) types or typologies based on actions, namely: 
1. Deviation from assets (Asset Misappropriation);Asset misappropriation includes abuse / theft of assets or property of the company or other parties. This is a form of fraud that is most easily detected because it is tangible or measurable (defined value).

2. Fraudulent Statement;Fraudulent statement includes actions taken by officials or executives of a company or government agency to cover the actual financial condition by conducting financial engineering (financial engineering) in the presentation of financial statements to obtain profits or may be analogous to the term window dressing.

3. Corruption.This type of fraud is the most difficult to detect because it involves cooperation with other parties such as bribery and corruption, where this is the most common type in developing countries where law enforcement is weak and there is still lack of awareness of good governance so that the integrity factor is still questionable. This type of fraud often cannot be detected because the parties working together enjoy benefits (mutualism symbiosis). Included in this is abuse of authority / conflict of interest, bribery, illegal gratuities and economic extortion.

Delf (2004) added another fraud typology, namely cybercrime. This is the most sophisticated type of fraud and is carried out by parties who have special expertise that is not always owned by other parties. Cybercrime will also be the most feared type of fraud in the future where technology is growing rapidly and sophisticated.

\section{Methodology}

This study uses descriptive qualitative methods through normative sociological, cultural, and juridical approaches to policies, and norms that apply to banking. Approaches are taken through FGDs by involving decision makers at the head office / branch level, as well as experts and banking practitioners to get ideas / input. The thought of the results of the FGD will be reconfirmed with the experts and practitioners, then formulated in an initial concept that will be input to management in the effort to prevent fraud in banking.

For more details, it can be explained in the following flow chart: 


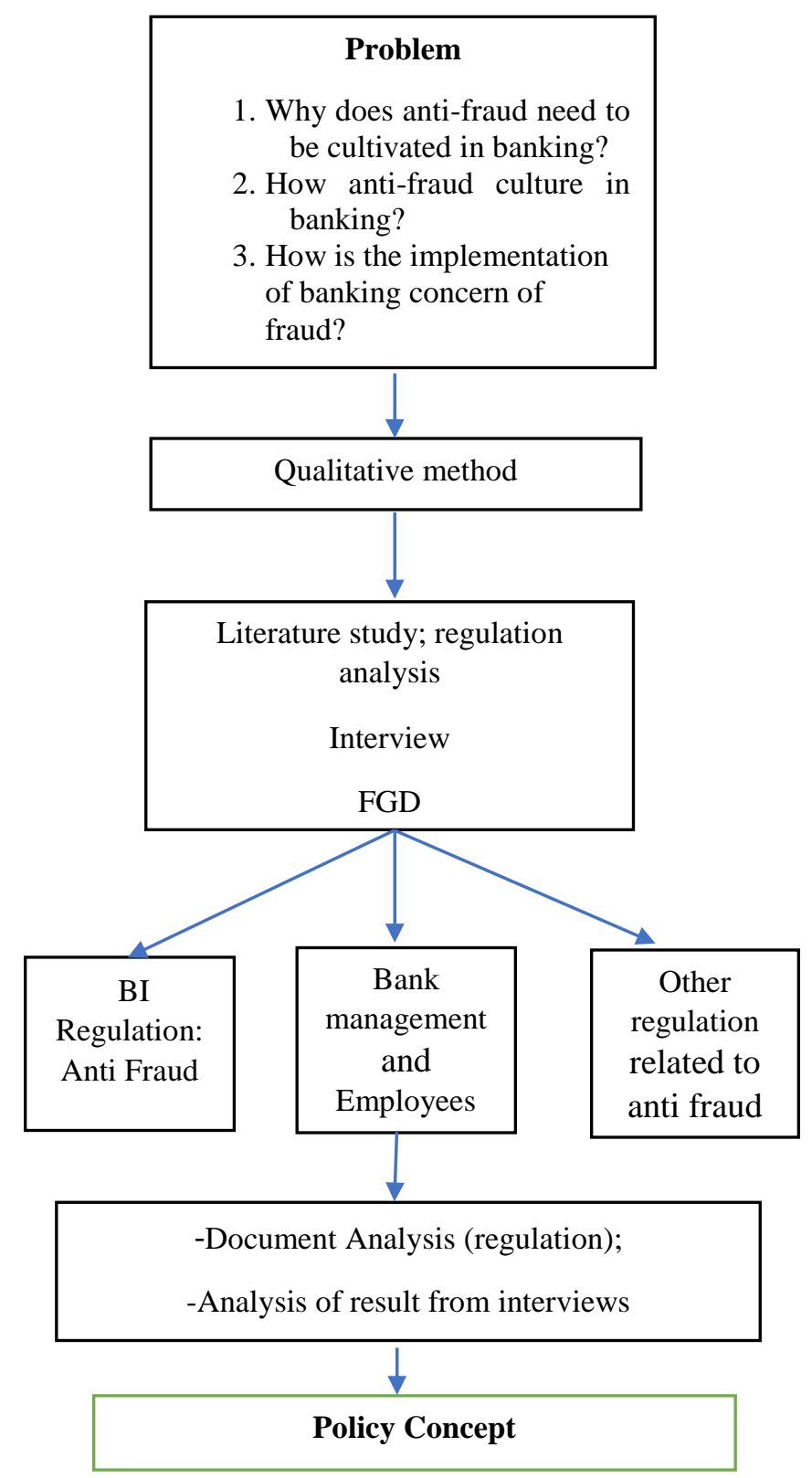

\section{Result And Discussion}


Banking fraud modes, particularly in the $\mathrm{X}$ bank, continue to grow. This crime no longer only targets the asset side, but also begins to develop on the liability side. The modus operandi is now not only assets such as fictitious credit or collection, but has already been in liabilities, such as deposits, and savings collection problems.

In the figure of preventing cases of banking operational irregularities, especially fraud that can harm customers or banks, training is needed in an effort to Build Anti Fraud Culture Through Working Ethos.

Training is needed to improve the effectiveness of internal control as an effort to minimize the risk of fraud by building an anti-fraud culture. The effectiveness of fraud control which is basically the responsibility of management, therefore, it requires proper and thorough understanding of fraud. Therefore, it requires direction and fosters awareness to control the risk of fraud in banks.

The strategy to build an anti-fraud culture is a manifestation of the bank's management commitment in controlling fraud that is implemented in the form of fraud control systems. This strategy requires management to direct resources so that fraud control systems can be implemented effectively and sustainably.

After participating in the training the participants will be able to:

1. Explain the purpose and understand the analysis of banking crime modes

2. Determine and develop strategies to minimize fraud

3. Develop fraud analysis so that it can anticipate

4. Identify patterns and insights before fraud occurs

5. Creating a healthy work culture in each business unit

6. Implement business ethics so as to realize a healthy and transparent business climate

7. Understand and ensure effective and efficient implementation of countermeasures and steps to prevent fraud through case studies in financial institutions.

The Central Statistics Agency (BPS) writes that the cultural roots of corruption are: There is a tradition of giving gifts, gifts or the like to government officials. Such actions in Europe or North America can be considered corruption as a form fulfillment of obligations by the subjects to the gust. Family ties and parochial loyalty in Eastern communities like Indonesia are still considered very important. One's obligation is first to pay attention to you closest, then breed or fellow ethnic. In this kind of culture if there is someone who came to his brother who was an official to ask for special treatment was difficult to reject. Rejection can be interpreted as a denial of traditional obligations, but obey demand means denying the prevailing formal legal norms. So always value conflicts occur, namely between cultural norms or formal legal norms.

\section{Conclusion}

Bank Indonesia through several regulations related to fraud requires banks to have and implement anti-fraud policies. This is an attempt to cultivate and care about fraud as a strategic part of the banking sector. Regarding fraud, the Bank needs to implement Risk Management with reinforcement in several aspects, which at least includes Active Supervision Management, Organizational Structure and Accountability,and Control and Monitoring. 


\begin{abstract}
Aknowledgements
In this study, I would like to thank the Director of the Jakarta State Polytechnic, Head of the Research and Community Services Center (P3M), and the Accounting Department Lecturer, Head and Lecturer of the Accounting Department, Mr. Priyo from the Financial Services Authority. Student (Suryo Hapsoro) Jakarta Police Science College who helped in the search for literature to complete this research report, Sister Prastiwi Rosita as the liaison banks, as well as all parties that have supported and helped implement this research.
\end{abstract}

\title{
References
}

[1] Adzani. Etika Perbankan. Accessed at http://aladzaniart.blogspot.com.html Februari 2015 (2012).

[2] Fauzi, Nurul. Implementation of Values Softskill in the Framework of Implementation of CompetencyBased Curriculum and Student Center Learning in the Accounting Department State Polytechnic Padang, Journal of Accounting \& Management, Vol.5, No.2, (2010)

[3] Institut Bankir Indonesia. Kode Etik Bankir. Jakarta (1994).

[4] Fauzi, Edi. Prospek Efektifitas Strategi Anti Fraud Bank Indonesia Sebagai Bentuk Pencegahan Kejahatan Perbankan (Suatu Penelitian Taknik Delphi Pendapat Para Pakar Perbankan). Tesis. Fakultas Ilmu Sosial Dan Ilmu Politik Departemen Kriminologi Un (2012).

[5] Pangaribuan, Daniel. Mencegah Korupsi Dengan Membangun Budaya Kejujuran dan Etika http://www.bppk.kemenkeu.go.id/id/publikasi/artikel/168-artikel-pengembangan-sdm/22871mencegah-korupsi-dengan-membangun-budaya-kejujuran-dan-etika (2016).

[6] Fresh Consultant. Membangun Budaya Anti Fraud Di BPR Melalui Etos Kerja. http://freshconsultant.co.id/2017/06/13/membangun-budaya-anti-fraud-di-bpr-melalui-etos-kerja/ Accessed at Saturday, 7 April (2018).

[7] Sula, Emilia. A. Dan kawan-kawan. 'Pengawasan, StrategiAnti Fraud, Dan Audit Kepatuhan Syariah Sebagai Upaya Fraud Preventive Pada Lembaga Keuangan Syariah'. JAFFA Vol. 02 No. 2, 91 - 100 (2014)."

[8] YR. Dewi, Rozmita dan Ariandi, Irfan. The effect of internal control and anti-fraud awareness on fraud prevention (A survey on inter-governmental organizations).Jurnal Ventura.Vol. 20.No.1. Akreditasi No: 80/DIKTI/Kep./2012. https://journal.perban (2012). 